\title{
ATIVISMO JUDICIAL E A (IN)COMPATIBILIDADE COM O ESTADO DEMOCRÁTICO DE DIREITO
}

\section{JUDICIAL ACTIVISM AND (IN) COMPATIBILITY WITH THE DEMOCRATIC STATE OF LAW}

ROGELSON LUIZ VIEIRA JÚNIOR

Acadêmico do curso de Direito da Faculdade do Litoral Paranaense - ISEPE GUARATUBA.

\section{ROGÉRIO SILVA BERNARDI}

Mestrando em Direitos Humanos e Políticas Públicas pela Pontifícia Universidade Católica do Paraná - PUCPR; Professor na Faculdade do Litoral Paranaense - ISEPE GUARATUBA.

\section{RESUMO}

O presente trabalho tem por escopo analisar a compatibilidade entre 0 ativismo judicial e o Estado Democrático de Direito, fenômeno que põe em pauta um intenso debate sobre a constitucionalidade da atuação do Poder Judiciário, engajado no viés destinado a decisão dos magistrados, perfazendo uma constatação de tal panorama, a fim de verificar se tal prática reflete uma discricionariedade nas decisões proferidas que agem de maneira solipsista, dando azo ao julgador vestir-se de um espírito de legislador (hiper)ativista, seguindo a teoria constituída na Crítica da Hermenêutica Jurídica em Crise (STRECK, 2009), ou demonstra o resultado da concretização dos direitos e garantias previstos na Carta Magna e que carecem de um efetivação por parte do Poder Legislativo e Executivo, que é obtida mediante um 
Personalidade Acadêmica Homenageada:

Augustus B. Cochran III (Agnes Scott College)

dirigismo jurídico feito através dos magistrados para buscar um resultado do que acredita-se ser justiça fundamentando-se na ponderação de valores (BARROSO, 2009). O estudo ora realizado pretende buscar analisar o significado científico do termo (VALLE, 2009), o qual não é pacificado nas correntes doutrinárias a respeito da matéria (BARROSO, 2019) através de uma análise histórico e conceitual sobre como o ativismo judicial ocorreu nos Estados, Unidos, berço moderno de tal cenário, a partir do paradigmático caso Marbury x Madison (STRECK, 2010), a jurisprudência de valores, teorizada por Robert Alexy (TRINDADE e MORAIS 2011), e em como tais institutos influenciaram no ordenamento jurídico pátrio, realizando uma análise do entendimento jurisprudencial construído nos mais de 30 (trinta) anos de vigência da Constituição da República Federativa do Brasil de 1988 (STRECK, 2018). Esta monografia obteve como resposta de tal indagação que ainda não há um consenso exato sobre o sentido empregado do termo ativismo judicial (BARROSO, 2019), ocorrendo frequentes confusões entre ativismo judicial com a judicialização da esfera Política (BARROSO, 2009). Mesmo assim, ainda é possível verificar que é necessário o estabelecimento de um limite da atividade heurética do julgador para não quedar-se em um estado de discricionariedade/arbitrariedade onde não exista segurança jurídica, ocorrendo o denominado o protagonismo judicial (CASTRO e PAULA, 2018) presente em decisões onde o magistrado(a) manipula o texto legal através de uma subjetividade (excessivamente) inadequada a sua função (STRECK, 2010).

PALAVRAS-CHAVE: Ativismo judicial; Judicialização da política; Hermenêutica Jurídica; Ponderação de Valores; Jurisprudência dos valores; Protagonismo judicial.

\section{REFERÊNCIAS}

BARROSO, Luís Roberto. Judicialização, Ativismo Judicial e Legitimidade Democrática. [S.I.]: Migalhas, 2009. Disponível em: $<$ http://www.migalhas.com.br/arquivo_artigo/art20090130-01.pdf>. Acesso em: 05/02/2019.

Constitucionalismo Democrático: $A$ ideologia vitoriosa do século XX. Editora: Migalhas. Ribeirão Preto. 2019. 
Personalidade Acadêmica Homenageada:

Augustus B. Cochran III (Agnes Scott College)

. Curso de direito constitucional contemporâneo: os conceitos fundamentais e a construção do novo modelo. Editora: Saraiva Educação. $8^{\mathrm{a}}$ ed. São Paulo. 2019.

COURA, Alexandre Castro; PAULA, Quenya Correa de. Ativismo judicial e judicialização da política: sobre o substancialismo e procedimentalismo no Estado Democrático de Direito. Revista Brasileira de Estudos Políticos. Belo Horizonte, n. 116. p. 63-112, jan. /jun.2018.

STRECK, Lenio Luiz. $\mathbf{3 0}$ anos da CF em $\mathbf{3 0}$ Julgamentos. Uma radiografia do STF. Forense, $1^{\underline{a}}$ ed. São Paulo. 2018.

Hermenêutica Jurídica e(m) Crise. Uma exploração hermenêutica da construção do Direito. Editora: Livraria do Advogado. 8 ed. Porto Alegre. 2009

O que é isto - decido conforme minha consciência?. Editora: Livraria do Advogado. Volume 1. Porto Alegre. 2010.

TRINDADE, André Karma e MORAIS, Fausto Santos de. Ativismo Judicial: As Experiências Norte-Americana, Alemã e Brasileira. Revista da Faculdade de Direito. Curitiba, n. 53. p. 137-164, 2011. 